\title{
Urban Oasis: an integrated water shelter and city-scape beacon
}

\author{
Victoria Masterman, Lauren Heritage-Brand \\ The University of Adelaide, Australia \\ School of Architecture and the Built Environment \\ victoriamasterman@gmail.com | heritagebrand@live.com.au
}

\begin{abstract}
Urban densification and a global shift towards the creation of walkable neighbourhoods have generated demand for more sustainable transport models and supporting infrastructure. Transforming streetscapes from car dominated spaces to places for people. A review of public space allocation in streets demonstrates the need to re-prioritise and re-organise streets to provide improved infrastructure to meet present and future demands on transport corridors.

This paper proposes the creation of, an integrated design solution in the form of an urban 'Oasis' that provides a network of on street facilities for cyclists and pedestrians. Planning the network of 'Oasis' is informed by the principal of Link and Place creating a visual balance between vehicles and other street users while promoting sustainable ideologies. The 'Oasis' presents itself as a multi-purpose drink station, bus shelter, public seating area, bike rack, public art piece and environmental education tool that, at its core functionality, captures, stores and purifies rainwater so that commuters can park, rest and access water after a walk or ride to the station.

The paper explores available technologies and a range of modular adaptable designs to suit various urban landscapes. An integrated network of 'Oasis' transforms the street combining furniture combining cycling and pedestrian facilities, comfort and user friendliness, in a unique and attractive form. The development of the Oasis, draws on a range of fields including urban planning and design, landscape architecture, natural resource management, urban water engineering, digital communications and technologies and the visual arts.

This research demonstrates the potential flow-on benefits of the Oasis including improved road safety, increased patronage on public transport, increase in cycling, improved natural resource education and management, improved sense of place and foster community building.
\end{abstract}

Keywords: cyclability; modular; streetscape; urban infrastructure; network.

\section{To cite this article:}

Masterman V., Heritage-Brand L. (2017). Urban Oasis: an integrated water shelter and city-scape beaconThe Journal of Public Space, 2(I), I35-I46, DOI: 10.5204/jps.v2i I.56

This article has been peer-reviewed and accepted for publication in The Journal of Public Space. Please see the Editorial Policies under the 'About' section of the journal website for further information.

This work is licensed under a Creative Commons Attribution - Non Commercial 4.0 International License. https://creativecommons.org/licenses/by-nc/4.0/ 


\section{Introduction}

United Nation statistics suggest that by 2050 the world's urban population is projected to increase by 85 percent to 6.3 billion - two-thirds of the world's population (MAN, 2013:

4). Within this growth, urban planners must work toward a greater balance between uses and users and the battle for public space for transport purposes (MAN, 2013: 7). As cities throughout the developed and developing world experience the megatrend of urbanisation, the issue of public space allocation becomes an increasing matter of economic, social and environmental interest.

Cities including Adelaide, South Australia are forecasting significant growth in the inner urban population, requiring the implementation of planning mechanisms that allow for the creation of sustainable development through an increase in housing densities in inner urban areas, and the creation of transit growth corridors. Polices set in the South Australian Strategic Plan aim to decrease car dependence and increase patronage on public transport networks to $10 \%$ of total car and public transport use by 2018 (South Australian Government, 20I I: 47). It is envisaged this be achieved through the creation of accessible, safe and reliable mass transport networks. Upgrades and extensions to pedestrian and cycle networks (South Australia. Department of Planning and Local Government, 2010: 57). Implementation of these strategic goals aims to create an affordable and sustainable transport network that is adaptable and able to respond to the impacts of climate change.

The World Business Council for Sustainable Development (20l4), recognises the pivotal role infrastructure plays in achieving ambitious sustainability targets. Through the transformation in the design, construction and operation of infrastructure systems linkages between water, sanitation, telecommunication networks, waste management systems and building energy mobility are optimised (p. 22).

The Greater Adelaide 30-Year plan forecasts a population growth of 560,000 people, estimating an increase of $42 \%$ in trips to, from and within the city, accounting for approximately 100,000 people (South Australia, Department of Planning and Local Government, 2010: 90). To cater for this growth the Government is implementing major infrastructure projects to increase the efficiency and capacity of existing systems. However, accessibility to the 14 proposed Transit Oriented Developments (TOD) and associated infrastructure has limited impact on inner urban growth areas, where dependency on the car remains high. To plan for growth in housing densities in inner urban areas, located outside of the TOD zones, it is imperative that alternative and sustainable transport networks are developed, to reach the reduction in car dependency targets.

To address increased demands on the inner urban transport network, the Adelaide City Council developed the Smart Move Strategy, a I0-year transport and movement strategy, that aims to make the city more accessible through the development of safer and more connected streets (Adelaide City Council, 20I2).

One of the key aims of the strategy is to provide safe and convenient cycling options for people of all abilities, from the suburbs to the city and that cycling becomes the preferred mode of transport for localised trips, reducing reliance on the car. However, the plan is faced with many challenges, a relatively low proportion of the population currently choose to cycle to work, educating the broader population on the benefits and raising awareness of cyclists is needed and acceptance of changes to street prioritisation by both users and public space managers. Providing infrastructure solutions that increase safety 
for cyclists and provide quality end of trip facilities for cyclists is one initiative aimed at dealing with such challenges.

The alignment of Council (local government) and State (provincial government) strategies is critical to the success of proposed infrastructure changes; Table I highlights the integration of the two strategies.

\begin{tabular}{l|l}
\hline ADELAIDE CITY COUNCIL'S TARGETS & SOUTH AUSTRALIA'S STRATEGIC PLAN TARGETS \\
\hline $\begin{array}{l}\text { By 2022: } \\
\text { Complete The City of Adelaide's Bikeways } \\
\text { network }\end{array}$ & $\begin{array}{l}\text { Double the number of people cycling in South } \\
\text { Australia by } 2020 \text { (target 2) }\end{array}$ \\
\hline $\begin{array}{l}\text { Complete } 10 \mathrm{~km} \text { of separated bikeways } \\
\begin{array}{l}\text { Double the number of people cycling in the } \\
\text { City (baseline 20II) }\end{array}\end{array}$ & $\begin{array}{l}\text { Reduce road fatalities and serious injuries by at } \\
\text { least } 30 \% \text { by } 2020 \text { (Target 22) }\end{array}$ \\
\hline
\end{tabular}

Table I. Adelaide City Council and State cycling targets Source: Adelaide City Council, 2012, p. 36

Informed by the quality of cycling networks of Copenhagen, Portland and Bogotá, Adelaide is implementing changes that challenge the effects of traffic-dominated cities, focusing on improving the cyclability and walkability of urban centres (MAN 20I3). Facilities already in operation or development include cycle ways, (Fig. I.), bike-prioritised 'boxes' at traffic lights (Figure 2), improved pedestrian links through the city between key destinations such as public transport hubs and commercial zones, and broader infrastructure investment to develop TOD's that encourage public transport uptake.
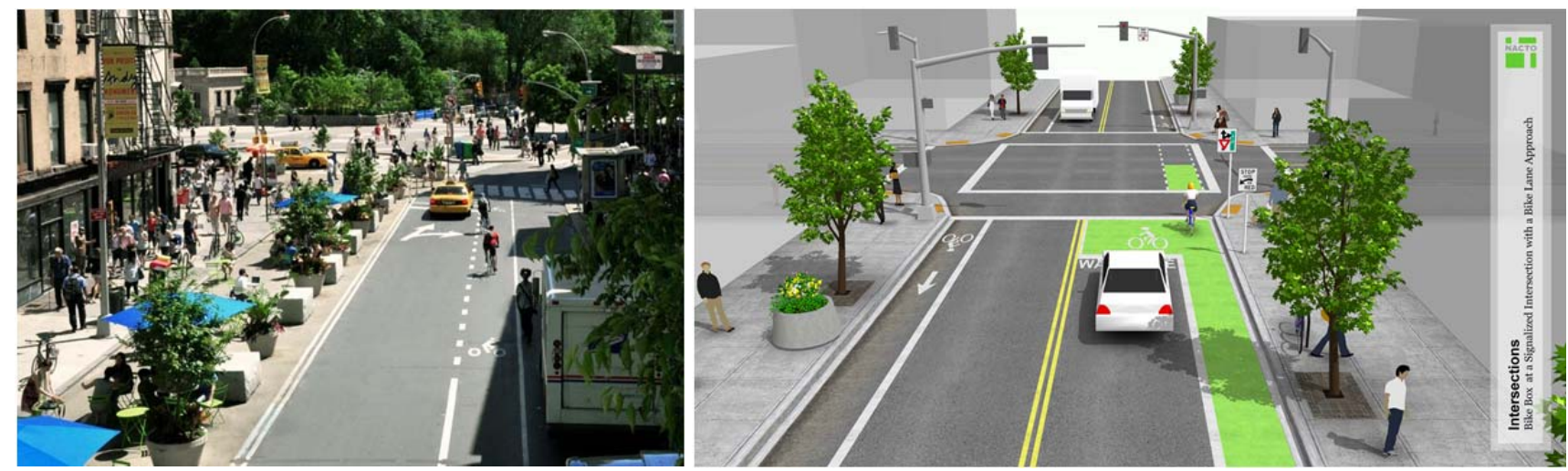

Fig. I (on the left). Broadway North, New York. Source: New York City Department of Transportation, 20II, p 3.

Figure 2 (on the right). Hearst Avenue Bike Box. Source: Campbell, 2013.

However, what becomes clear when examining the planning and provisioning of infrastructure for cyclists, pedestrians and other non-car users of the streetscape is that these cohorts are often being planned for separately, just as transport planning for motorised transport is usually planned for by its own group of planning specialists. 
This paper proposes that there may be benefits to establishing a collaborative partnership between cyclists, pedestrian and public transport users to plan for and provide multifunctional and visually stimulating infrastructure, as a means to regain balance, or reinforce the perception of greater balance, between private vehicles and 'other travellers'. Such visually appealing and functional places may be seen as beacons within the streetscape to serve as urban oasis for the other travellers.

To support cyclists and pedestrians beyond changes to road infrastructure, this paper explores the provision of an integrated network of facilities in the form of a modular adaptable shelter system. The urban 'Oasis' provides fresh drinking water for commuters, cyclists and pedestrians, through a catchment, filtration and storage system, a secure facility to store or hire bikes and equipment, and/or seating and shade to protect users while they wait for public transport. This multi-faceted facility harnesses digital technology that maps the location and information about each Oasis in the network, including the availability of parking, storage, and water and is easily accessible through an app. To raise awareness of the urban water management the app reports on water usage, availability and quality.

Planning for and provisioning oasis-like structures is presented from the position that combining the needs of currently separately-planning-for user groups (that being cyclists, pedestrians and other non-car travellers), can provide multiple benefits to the city through raising the visibility of these users, creating greater visual balance on the streetscape, improving safety and creating better quality places for people.

\section{Public Space Allocation and Reprioritisation of the Streetscape}

As asserted by Holyoak (20II), the travel needs of a population can be met in a more sustainable manner when careful consideration is given to a range of important aspects of the urban environment, transport infrastructure, governance and the needs of the community (p.I29). Bächtold (20I2) asserts two ratios of urban land allocation. The ratio of urban land allocation quantifies the ratio and density potential of land for private allotments to public space. This determines the quantity of taxes that contribute to the development of the land and for the ongoing maintenance of the land linked to adjoining public spaces. The ratio of public space allocation quantifies the areas of streets reserved for urban activities that characterise urban behaviour, including communication, leisure and exchange.

The two ratios are the cornerstones to the implementation of an economically viable integrated planning strategy and achieving the right balance between space allocations will determine the liveability of a city and the quality and functionality of public space.

(Bächtold, 20I2: 8).

The quantity and quality of space allocated to public transport, determines the mobility of the population, however in view of the cost of accessibility and the viability of a transport network, consideration needs to be made for not only the space required for transportation, but the space required by the modes of transport (Gonzales, 20I I: 2, 7). To improve mobility and provide both economically and environmentally sustainable transport options the reprioritisation of streets requires the reallocation of public space, to ensure users have access to safe alternative modes of transport.

The 20I 3 "What Cities Want" study run by the MAN Group indicated 14 out of I 5 cities consulted identified key objectives to improve mobility options for residents, including upgrading public transport infrastructure and improving the quality of local public 
transport services. This supports the reprioritisation of our streets and the reallocation of public space to provide more accessible, sustainable and integrated transport networks and associated infrastructure.

Reprioritisation of the streetscape can be seen in the shift in urban and traffic planning towards the provision of improved cycling infrastructure predominantly in the form of protected bike lanes (Figures 3 \& 4) and bike boxes to improve cyclists' safety. However, there is often a lack of supporting infrastructure for the cyclist.
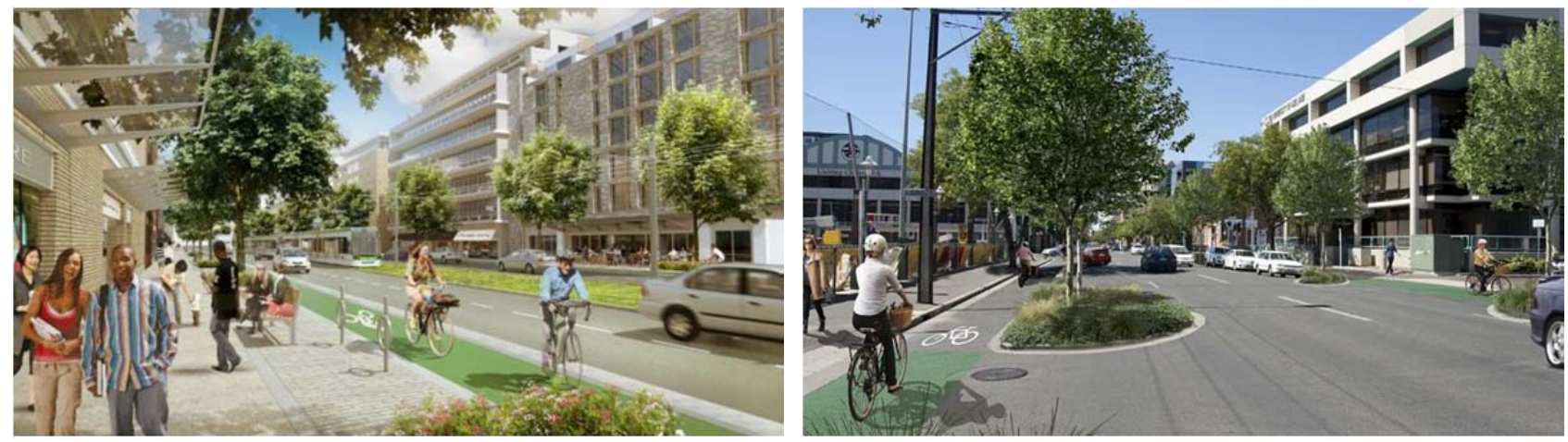

Fig. 3 (on the left). Eglinton, Toronto, Canada. Source: Kalinowski , 2014.

Fig. 4 (on the right). Frome Road, Adelaide, Australia. Source: Williams, 2014.

A modular and integrated system of the 'Oasis' can provide necessary urban infrastructure to support the reprioritisation of street design and the rising demand for safe cycle ways for the inner urban and recreational areas.

Supporting infrastructure in the form of an 'Oasis-like' public place will provide users with access to an integrated network providing water, shade and seating opportunities for social interaction, security, point to point travel stops towards destination, and with opportunities for personalisation of the structure and the integration of public seating creates a sense of place.

\section{Transforming the Streetscape}

A typological streetscape cross-section consists of a central roadway adjacent to pedestrian pavement and possible squares and other gathering spaces, bordered by private space at the outer limits (Figure 5). Within the streetscape, the constructed roadway in the centre often dominates the public space allocation.

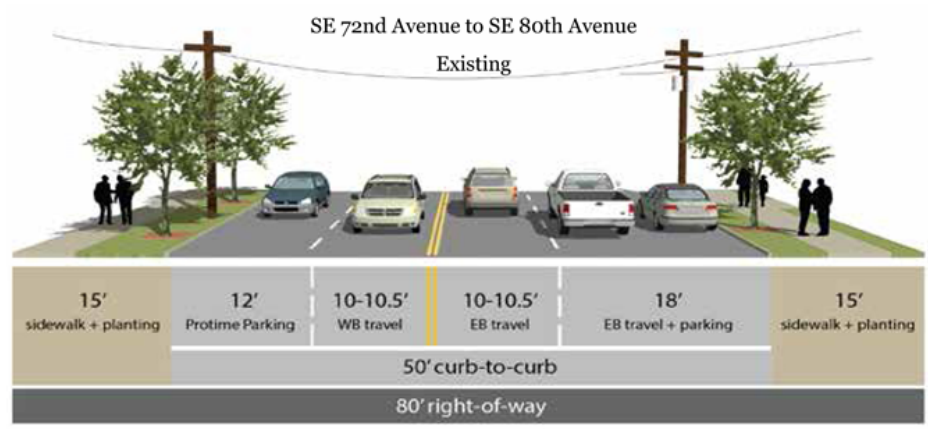

Fig. 5. Typical Existing Cross Section Foster Road, East Portland

Source: The Bureau of Transportation \& Portland Development Commission, 2014, p. 17 
Although this pathway is in many cases open to use by a range of motorised and humanpowered transport modes, in many cities, as is the case in Australia, it can be perceived as a public space primarily for vehicles. Such perceptions can be seen as a result of segregated public space design as explored by Hamilton-Baillie (2008). Replicated hundreds of thousands of times throughout the city, at every junction, street corner, laneway, highway, boulevard and road, the visual dominance of these roadways and the associated perception that their presence is primarily for cars, serves to reinforce the perception that cities serve to enable vehicle travel at the detriment of other users of the public space (Gehl, 20l0). Add to this, the allocation of private space within the urban environment for car parks, driveways, fuel stations, car washes and car sales yards, the (miss-led) perception that cities are places for cars - not people, is yet again reinforced by the visual urban landscape.

In rural areas, the dominance of the constructed roadway is less clear; where roads may be narrower and may be shared by vehicles, farm machinery, bicyclists, pedestrians and livestock. The scale of open space in the surrounding landscape can often further downplayed by the perception of the road being a dominant feature or function of the place.

The importance of visual dominance in a land- (or street-) scape can be demonstrated in rural areas where there are objections to the construction of wind turbines or wind farms. However, along with objections there can also be support for these structures which, to some, appear as an appealing architectural element that also serves as a reminder of the role of clean-energy production and more sustainable energy consumption (LandWorks, 2006). Such support and objection once again reinforces how the visual environment can help or hinder the ideologies and visions for the area, whether urban or rural.

In the urban context, where many cities are moving towards sustainable ideologies and the promotion of human-powered transport and urban design (Gehl, 20l0), this paper proposes that the creation of oasis-like infrastructure, designed and provisioned to promote more visual balance between vehicles and other street users as well as promote sustainable ideologies, may provide flow-on benefits including improved road safety, increased public transport patronage, increases in cycling, improved natural resource education and management, improved sense of place and foster community building. There are many success stories of transformations and reprioritisation efforts. For example in New York City, the 2009 Green Light for Midtown Project saw the reprioritisation of roadways and establishment of the Broadway pedestrian zones (Figure I). Through analysis of traffic flow and pedestrian movement data, as well as land value/retail market data assessed before and after the project, the area has seen an increase in travel speeds for both taxis and buses and a vast improvement in safety aspects with fewer pedestrian, motorist and passenger injuries, as well as increasing market values in retail spaces adjacent to pedestrian zones (DOT, 20I0).

\section{Oasis: Link and Place, Design, Integration and Functionality}

Link and Place

In Border Country, Williams is 'fascinated by the networks men and women set up, the trails and territorial structures they make as they move across a region, and the ways these interact or 
interfere with each other' (Sheller, 2000, Pinkey, 199I, Williams, 1988). The 'Oasis' supports this assertion, as an iconic structure or beacon in the urban landscape; the core structure and functionality will remain constant however, the modular system allows for the customisation of the structure to ensure its appropriateness for its location.

The planning, design and implementation of the 'Oasis' network will be informed through the application of 'Link and Place'. A street classification tool will support planning for the provision of appropriate infrastructure to support cyclists and commuters with a specific street 'structure' (Figure 6).

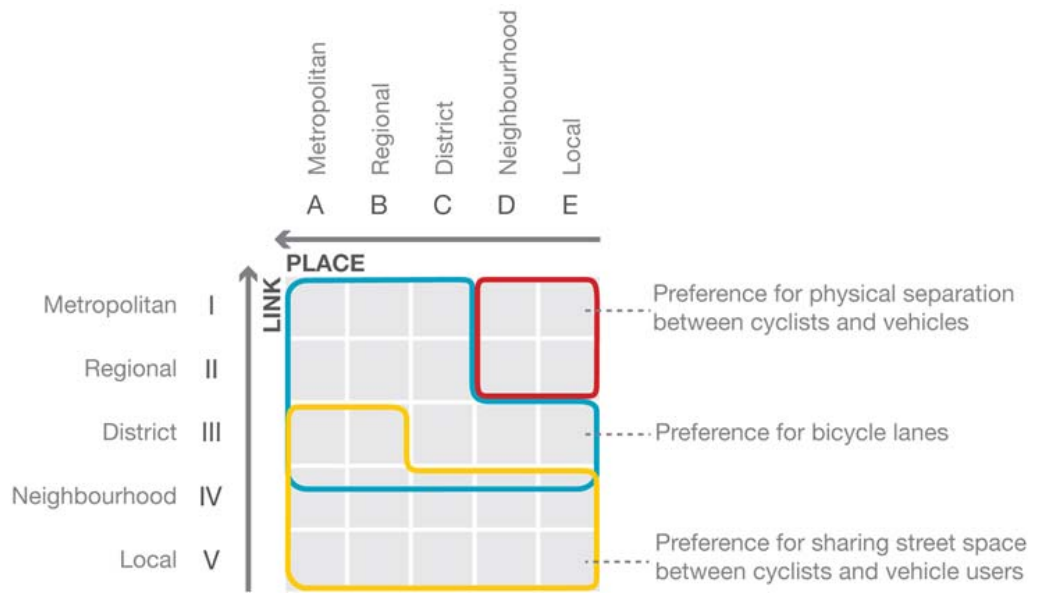

Fig. 6. Indicative street typologies for mixing and segregating on-road cyclists with general traffic, in desirable speed environment

Source: Boujenko, Morris, \& Jones, (20/2). Adelaide, S. Aust: Government of South Australia, p. 52.

'Link' refers to the street as a conduit, within the broader urban streetcape network, and more specialised, urban transport networks. The key objective of 'Link' is to save time. 'Place' refers to the street as a destination, a place to linger and to spend time. (Jones, Boujenko, \& Marshall, 2007). The application of the Link and Place as an approach to planning for cycling infrastructure generates solutions that are more appropriate to the site and more likely to meet stakeholder approval and create a sense of ownership. The tool will assist in creating a more visual balance within the streetscape as it will guide the identification of which module is appropriate for the site. The tool can be applied at a metropolitan, regional, district, neighbourhood and local level, allowing for the gradual implementation of the Oasis network.

Design

The aim of the design of the Oasis is to support urban creativity and create a sense of ownership by the broader community with a customisable design that provides opportunities for the integration of public art reflective of the community and urban environment in which it is proposed (Fusco, Levent, \& Nijkamp, 20I I, p. I).

Urban design should be creative and allow the community to become actively engaged in the design process, to explore options, incorporate new or site specific materials to create a sense of ownership (Boujenko, Morris, \& Jones, 2012 Adelaide, S. Aust: Government of South Australia., p. 30). The inclusion of customisable public art within the Oasis, aids in promotion creative urban initiatives and with the incorporation visual 
art, structures are less likely to be impacted by graffiti. An additional smart phone technology may allow users to 'tag' their local Oasis via an interactive visual display that responds to the arrival of registered users, as they 'check-in' at the Oasis, thereby providing personalisation akin to graffiti tagging.

The design of the Oasis presents a range of modular, adaptable solutions to suit various urban landscapes. The main structure takes on three forms, each with a core structure and adaptable interchangeable elements. Key features include bike storage, lockers, seating and bike pumps, access to purified water, lighting and shelter. Refer Figures 7-I0.

\section{Functionality}

Oasis proposes a unique combination of technologies offering pedestrians, cyclists and commuters with an easily accessible functional space and also aids in community placemaking and environmental education. The Oasis will be an easily identifiable beacon in the urban landscape. Encouraging and supporting sustainable mobility to and highlighting the value of urban water security to everyday users and providing more detailed reports on water storage, usage and quality to urban water managers. The Oasis can be installed gradually to meet the current and future demands of urban dwellers providing key facilities to encourage more people to participate in more sustainable transport methods. With the integration of rainfall data and storage capacities of each Oasis into smart city monitoring capabilities, urban water managers can incorporate this data into emergency water supply capacities, supporting urban climate change resilience strategies.
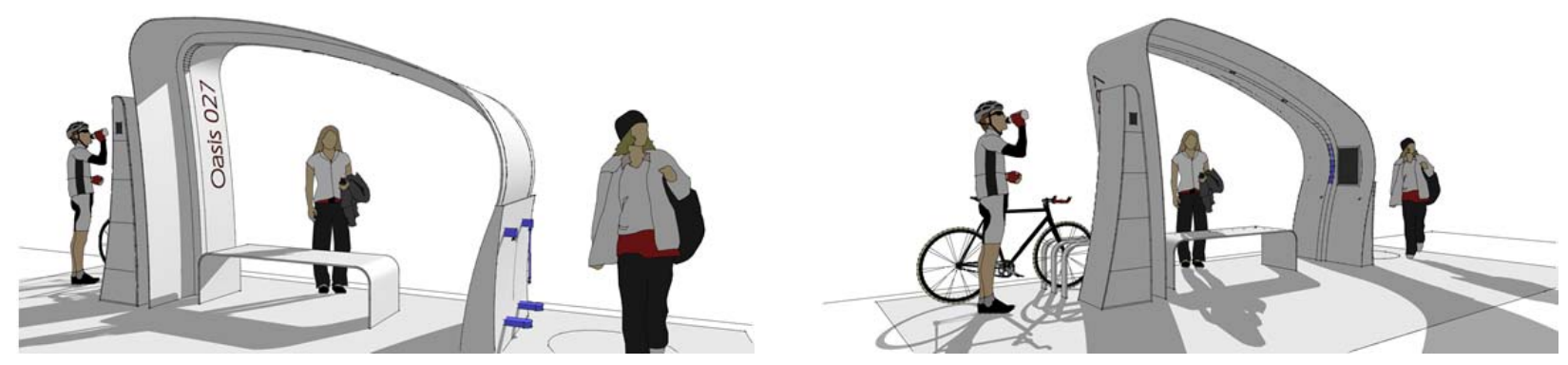

Fig. 7-8. Oasis, integrating bike storage including bike racks, lockers, bike pump, purified water, seating, underground water storage to reduce the structure footprint in the urban streetscape.
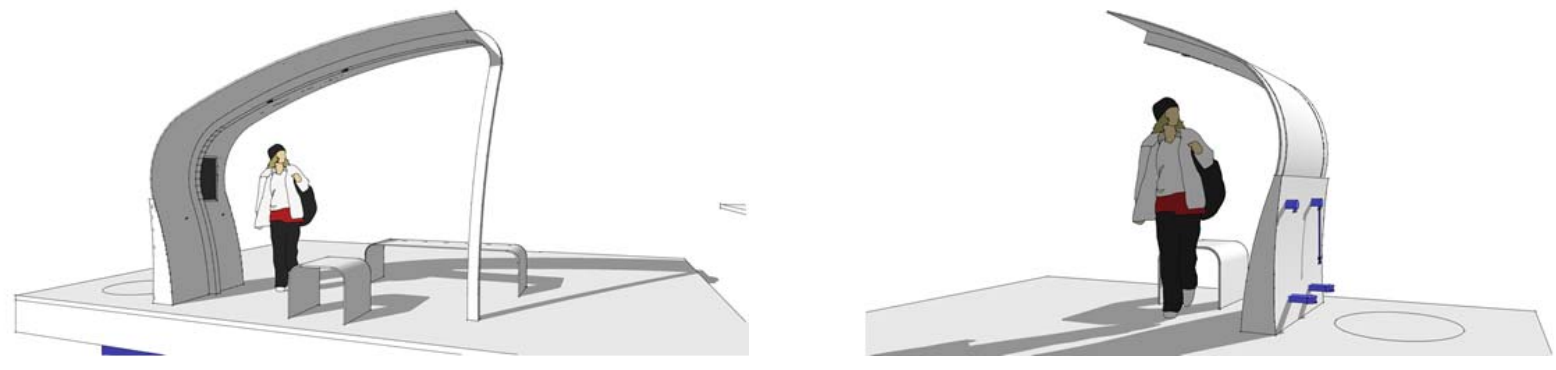

Fig. 9 (on the left). 'Oasis Midi', for streets with a high link status and low place status, Fig. 10 (on the right). 'Oasis Mini', for shared use paths, along linear parks.

The urban Oasis focuses on integrating currently separate pieces of infrastructure in public spaces to support bike riders, walkers and non-car travellers enhanced by the 
application of smart phone technology, while providing new facilities and functions. Each Oasis is numbered and mapped allowing users to map proposed paths of travel or select preferred destinations based on the functionality of the individual 'Oasis'. Refer to Table 2 for levels of network integration and Table 3 for standard features and options.

\begin{tabular}{|c|c|c|c|c|}
\hline \multirow{2}{*}{ COMPONENT } & \multirow{2}{*}{$\begin{array}{l}\text { INTEGRATION } \\
\text { SUMMARY }\end{array}$} & \multicolumn{3}{|c|}{ LEVEL OF NETWORK INTEGRATION } \\
\hline & & LOCAL & NATIONAL & GLOBAL \\
\hline \multirow{3}{*}{$\begin{array}{l}\text { Water } \\
\text { Management } \\
\text { System }\end{array}$} & $\begin{array}{l}\text { Ecovision System } \\
\text { providing real-time } \\
\text { weather and Rainfall } \\
\text { data }\end{array}$ & $\begin{array}{l}\text { Remote rainfall } \\
\text { data collected from } \\
\text { the BOM (I) } \\
\text { Interaction via the } \\
\text { 'Oasis' touch } \\
\text { screen and } \\
\text { Smartphone } \\
\text { Application }\end{array}$ & $\begin{array}{l}\text { Compare rainfall data } \\
\text { from 'Oasis' of a } \\
\text { comparable size within } \\
\text { the national Oasis } \\
\text { network, via 'Oasis' } \\
\text { touch screen \& } \\
\text { dedicated website }\end{array}$ & $\begin{array}{l}\text { Compare the rainfall } \\
\text { data from within the } \\
\text { global network of } \\
\text { Oasis sites } \\
\text { worldwide, though a } \\
\text { dedicated website }\end{array}$ \\
\hline & $\begin{array}{l}\text { Ecovision System } \\
\text { providing real time } \\
\text { storage levels, water } \\
\text { usage and } \\
\text { supplementary } \\
\text { potable water usage } \\
\text { data }\end{array}$ & $\begin{array}{l}\text { Visual indicators of } \\
\text { Water Quality and } \\
\text { storages levels via } \\
\text { LED lights along } \\
\text { the spine of the } \\
\text { Oasis and } \\
\text { Smartphone App }\end{array}$ & $\begin{array}{l}\text { Compare 'Oasis' water } \\
\text { storage data from } \\
\text { within the national } \\
\text { Oasis network of Oasis } \\
\text { via a dedicated website }\end{array}$ & $\begin{array}{l}\text { Compare 'Oasis' } \\
\text { water storage data } \\
\text { from within the global } \\
\text { Oasis network via a } \\
\text { dedicated website }\end{array}$ \\
\hline & $\begin{array}{l}\text { Ecovision System } \\
\text { providing water } \\
\text { quality data }\end{array}$ & $\begin{array}{l}\text { Users are able to } \\
\text { see the quality of } \\
\text { the water collected } \\
\text { and quality of the } \\
\text { water delivered }\end{array}$ & $\begin{array}{l}\text { Compare 'Oasis' water } \\
\text { quality data from within } \\
\text { the national Oasis } \\
\text { network of Oasis via a } \\
\text { dedicated website }\end{array}$ & $\begin{array}{l}\text { Compare 'Oasis' } \\
\text { water quality data } \\
\text { from within the global } \\
\text { Oasis network via a } \\
\text { dedicated website }\end{array}$ \\
\hline $\begin{array}{l}\text { Air Quality } \\
\text { Management } \\
\text { System }\end{array}$ & $\begin{array}{l}\text { Ecovision System } \\
\text { providing Air Quality } \\
\text { Data reporting }\end{array}$ & $\begin{array}{l}\text { Compare air } \\
\text { quality levels the } \\
\text { 'Oasis' via touch } \\
\text { screen and } \\
\text { Smartphone } \\
\text { Application }\end{array}$ & $\begin{array}{l}\text { Compare 'Oasis' air } \\
\text { quality data from within } \\
\text { the national Oasis } \\
\text { network of Oasis via a } \\
\text { dedicated website }\end{array}$ & $\begin{array}{l}\text { Compare 'Oasis' air } \\
\text { quality data from } \\
\text { within the global } \\
\text { Oasis network via a } \\
\text { dedicated website }\end{array}$ \\
\hline $\begin{array}{l}\text { Solar Panels } \\
\text { and Energy } \\
\text { Management } \\
\text { System }\end{array}$ & $\begin{array}{l}\text { Ecovision System } \\
\text { providing real-time } \\
\text { energy data and the } \\
\text { provision of power to } \\
\text { support the LED } \\
\text { lighting \& 'Oasis' } \\
\text { touch screen }\end{array}$ & $\begin{array}{l}\text { Real-time energy } \\
\text { production and } \\
\text { usage data the } \\
\text { 'Oasis' via touch } \\
\text { screen and } \\
\text { Smartphone } \\
\text { Application }\end{array}$ & $\begin{array}{l}\text { Compare 'Oasis' } \\
\text { energy production and } \\
\text { consumption levels } \\
\text { from within the } \\
\text { national Oasis network } \\
\text { of Oasis via a dedicated } \\
\text { website }\end{array}$ & $\begin{array}{l}\text { Compare 'Oasis' } \\
\text { energy production } \\
\text { and consumption } \\
\text { levels from within the } \\
\text { global Oasis network } \\
\text { via a dedicated } \\
\text { website }\end{array}$ \\
\hline Seating & Local User & Local user & $N / A$ & $N / A$ \\
\hline Bike Storage & $\begin{array}{l}\text { Sensors indicate real- } \\
\text { time availability of } \\
\text { bike parking }\end{array}$ & $\begin{array}{l}\text { Real-time booking } \\
\text { system through the } \\
\text { Smartphone } \\
\text { application }\end{array}$ & $\begin{array}{l}\text { National Data collected } \\
\text { on bike parking usage } \\
\text { figures }\end{array}$ & $\begin{array}{l}\text { Global Data collected } \\
\text { on bike parking usage } \\
\text { figures }\end{array}$ \\
\hline $\begin{array}{l}\text { Locker Storage } \\
\text { System }\end{array}$ & $\begin{array}{l}\text { Managed through } \\
\text { smart phone } \\
\text { technology }\end{array}$ & $\begin{array}{l}\text { Local user } \\
\text { engagement, via } \\
\text { remote booking via } \\
\text { Smartphone app or } \\
\text { at the Oasis }\end{array}$ & $\begin{array}{l}\text { National Data collected } \\
\text { on bike parking usage } \\
\text { figures }\end{array}$ & $\begin{array}{l}\text { Global Data collected } \\
\text { on bike storage } \\
\text { figures }\end{array}$ \\
\hline
\end{tabular}

Table 2. Oasis Network Integration.

(I) BOM, Australian Bureau of Meteorology 
Urban Oasis: an integrated water shelter and city-scape beacon

\begin{tabular}{l|l|l|l}
\hline & FUNCTIONALITY & \multicolumn{2}{l}{} \\
\hline FEATURES & OASIS & OASIS MIDI & OASIS MINI \\
\hline Fresh Water & $\times$ & $\times$ & $\times$ \\
\hline Seating & $\times$ & $\times$ & $\times$ \\
\hline Shelter & $\times$ (up to 6) & $\times$ (up to 4) & $\times$ (up to 2) \\
\hline Lighting (Solar) & $\times$ & $\times$ & $\times$ \\
\hline Water Quality Reporting & $\times$ & $\times$ & $\times$ \\
\hline Equipment Storage & $\times$ & Optional & Optional \\
\hline Bike Storage & $\times($ up to 4) & Optional & Optional \\
\hline Bike Repairs & $\times$ & $\times$ & $\times$ \\
\hline
\end{tabular}

Table 3. Facility options.

Placement and density of the Oasis network will be dependent on population and housing densities, demand and location.

The standard Oasis is predominantly located a key end and nodal points in the network, where demand for storage is greater. In highly urbanised area's the standard 'Oasis' may be located with $200 \mathrm{~m}$ walking distance within areas of high housing density and commercial business areas and intermediately along key transport routes. With frequency reducing as housing and commercial business densities decrease. The Oasis 'Midi' is located at intermediate points in the transport network and the Oasis 'Mini' is proposed for more remote locations.

\section{Conclusion}

Provision of urban infrastructure to support and guide growth in our cities in a manner that supports Link and Place planning, fosters community building, contributes to the health and well-being of its citizens and integrates within a smart city model, is a practical approach in the face of the global urbanisation megatrend.

The Oasis concept suggested in this paper is but one of a number of potential design solutions that can deliver quality public spaces and serves to inspire new approaches to planning, identifying opportunities to combine the needs of several user groups and creating greater perceived balance within the streetscape in a visually pleasing and truly multi-functional place. In this way the urban oasis concept presented here may be seen as a beacon, calling together a range of fields, thinking and technologies within the urban management system, and offering a place for all. 


\section{Acknowledgements}

We acknowledge the valuable contributions made by members of the project team, Clint Watchman, Urban Designer, for his work on the design of the "Oasis" and production of design drawings; Marco Meuller, Master in Lightweight Engineering Student, Chemnitz University of Technology, Germany; Kirsten Heritage, Lecturer, School of Creative Arts, James Cook University, Australia.

\section{References}

Boujenko, N., Morris, P., \& Jones, P. (2012 Adelaide, S. Aust: Government of South Australia.). Streets for People: Compendium for South Australian Practice. Retrieved from SA Active Living Coalition website: http://saactivelivingcoalition.com.au/streets-for-peoplepdf-downloads/

The Bureau of Transportation, \& Portland Development Commission (20I4). Foster Road Transportation and Streetscape Plan. Retrieved from https://www.portlandoregon.gov/transportation/article/484883

Bus Rapid Transit Policy Center (2007, February). Bus Rapid Transit Policy Center. Retrieved April 7, 20 I4, from http://www.gobrt.org/Transmilenio.html

Bächtold, B. (2012). The Space-Economic Transformation of the City: Toward Sustainability.

Campbell, D. (2013, July 8). From DIY Bike Lane to $\$ 3$ Mil Complete Street | Bike East Bay. Retrieved April 7, 2014, from https://www.ebbc.org/Hearst

DOT (2010) Greenlight for midtown evaluation report. New York City: Department of Transport.

Fusco, G. L., Levent, T. B., \& Nijkamp, P. (20II). Sustainable city and creativity: Promoting creative urban initiatives. Farnham, Surrey: Ashgate.

Gehl, J. (2010). Cities for people. Washington, DC: Island Press.

Gehl, J., \& Gemzoe, L. (2004). Public spaces, public life: Copenhagen. Copenhagen, Denmark: Danish Architectural Press and the Royal Danish Academy of Fine Arts, School of Architecture Publishers.

Gehl, J., \& Soholt, H. (2002). Public spaces and Public Life: City of Adelaide. Adelaide, SA, Australia: Planning SA.

Gehl Architects, \& Pasteinplace (2013, March). Bicycle Tracks vs City Roads [Infographic]. Retrieved from http://readerareadevelopment.com/2013/03/02/staturday-bikes-save-bucks/

Gonzales, Eric Justin (201 I). Allocation of Space and the Costs of Multimodal Transport in Cities. Retrieved from eScholarship, University of California website: http://www.escholarship.org/uc/item/0gw4x9kr

Gonzales, E. J., Geroliminis, N., Cassidy, M. J., \& Daganzo, C. F. (2010). On the allocation of city space to multiple transport modes. Transportation Planning and Technology, 33(8), 643-656. doi: I0.1080/03081060.2010.527|7|

Hamilton-Baillie, B. (2008). Shared spaces: Reconciling people, places and traffic. Built Environment, 3 (2), pp. $|6|-|8|$.

Henderson, J. (20II). Level of service: the politics of reconfiguring urban streets in San Francisco, CA. Journal of Transport Geography, 19(6), II 38-I I 44. doi:10.1016/j.jtrangeo.2011.05.010

Jones, P., Boujenko, N., \& Marshall, S. (2007). Link and Place: A Guide to Street Planning and Design. London, England: Local Transport Today Ltd.

Holyoak, N. (20I I). Sustainable transport planning and urban communities in Roetman P. E. and Daniels C. B (eds) Creating Sustainable Communities in a Changing World. Adelaide, SA, Australia: Crawford Publishing House.

Kalinowski, T. (2014, April 14). Eglinton LRT plan calls for $\$ 150$ million in streetscaping | Toronto Star. Retrieved April 7, 2014. Retrieved from: http://www.thestar.com/news/gta/2014/04/II/eglinton_Irt_plan_calls_for_150_million_in_stre etscaping.html 
Koohsari, M., Karakiewicz, J., \& Kaczynski, A. (2010). Public Open Space and Walking: The Role of Proximity, Perceptual Qualities of the Surrounding Built Environment, and Street Configuration. Environment and Behavior, 45(6), pp. 706-736.

LandWorks. (2006). Aesthetic assessment of the propose Sheffield Wind Farm. Retrieved June 9 , 20I4, from http://psb.vermont.gov/sites/psb/files/orders/2013/2013-12/Ex.\%20DR-2\%20\%20Visual\%20Assessment\%20Report.pdf

McLaughlin, K. (20I3). Bike city: officials aim to build on momentum for cycling. Indianapolis Business Journal, 34(33), 3. Retrieved from http://go.galegroup.com/ps/i.do?id=GALE\%7CA34930682 I \&v=2. I \&u=adelaide\&it=r\&p=ITOF\&s $w=w \& a s i d=8 e 9 b 52$ Ifd7d5fe6907f66 I425e I7ce9f

New York City Department of Transportation (20I I, August 22). Broadway: Union Square Plazas, Promenade and Bicycle Path. Retrieved from http://www.nyc.gov/html/dot/downloads/pdf/20I I0822_union_square_update.pdf

Pucher, J., Buehler, R., \& Seinen, M. (20I I, July). Bicycling renaissance in North America? An update and re-appraisal of cycling trends and policies. Retrieved May 25, 2014, from http://ac.elscdn.com.proxy.library.adelaide.edu.au/S09658564I I000474/I-s2.0-S09658564I I 000474 main.pdf? tid=f6a9 $17 \mathrm{c} 0$-e4d I $-\mid$ l le3-b2f500000aab0f26\&acdnat $=\mid$ 40 I I 07798_| 48df6b I d974f5328c97c796cd0b l e6

Sheller, M., \& Urry, J. (2000). The City and the Car. International Journal of Urban and Regional Research, 24(4), pp. 737-757. doi:I0. I I I I/ 1468-2427.00276

South Australia. Department of Planning and Local Government (2010). The 30-year plan for greater Adelaide: A volume of the South Australian planning strategy. Retrieved from Dept. of Planning and Local Government website: http://www.plan4adelaide.sa.gov.au/index.cfm

South Australian Government (20II). South Australia's Strategic Plan. Retrieved from http://saplan.org.au/media/BAhbBlsHOgZmSSIhMjAxMS8xMS8wNC8wMV8wMI8xNF8yMjNFZ mlsZQY6BkVU/0I_02_14_223_file

MAN (2013). What Cities Want: How Cities Plan for future Mobility. Retrieved from http://www.man.eu/man/media/en/content_medien/doc/global_corporate_website_l/presse_u nd medien I/2013 I/man_wcw_2013.pdf

Williams, T. (2014, April 25). The Advertiser. Retrieved April 7, 20I4, from http://www.adelaidenow.com.au/news/adelaide-city-councillor-mark-hamilton-will-push-for-thefrome-st-bike-lane-to-be-scrapped/story-fni6uok5-I226895877873

World Business Council for Sustainable Development (2014). The urban infrastructure initiative: Final report, Retrieved from http://www.wbcsdpublications.org/cd_files/datas/business_applications/uii/pdf/UII\%20Report.\%2 OFINAL.240320I4.pdf 